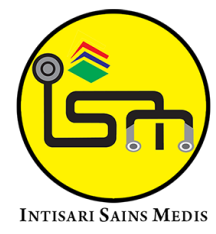

Published by Intisari Sains Medis

\title{
Hubungan nilai Red Cell Distribution Width (RDW) dengan tingkat keparahan pneumonia pada pasien anak di RSUD Wangaya Denpasar, Bali-Indonesia
}

Made Cynthia Mahardika Putri ${ }^{*}$, I Wayan Bikin Suryawan², I Kadek Suarca²

\section{ABSTRACT}

Background: Pneumonia is the highest cause of death in children less than five years old. Based on the 2019 Indonesian Health Profile, there were $52.7 \%$ cases of childhood pneumonia in Indonesia. The high number of deaths from pneumonia in children indicates the severity of the symptoms and the clinical deterioration that occurs, so it is essential to find markers that can predict children who are likely to experience clinical deterioration. Red cell distribution width (RDW) is a marker on standard blood tests but is rarely seen clinically. This study aimed to determine the relationship between the RDW value and the severity of pneumonia in pediatric patients.

Methods: The type of research used is an observational analytic study with a cross-sectional approach. Sampling used the consecutive sampling method. The data obtained were analyzed analytically, using the computer program SPSS version 25.0 with chi-square test and independent $t$-test.

Results: The mean RDW was higher in person with severe pneumonia $(15.48 \pm 1.95)$ than the group with mild pneumonia $(13.73 \pm 1.11)(p=0.000)$.

Conclusion: There is a significant relationship between RDW and the severity of pneumonia.

Keywords: Red cell distribution width, pneumonia, severity.

Cite This Article: Putri, M.C.M., Suryawan, I.W.B., Suarca, I.K. 2021. Hubungan nilai Red Cell Distribution Width (RDW) dengan tingkat keparahan pneumonia pada pasien anak di RSUD Wangaya Denpasar, Bali-Indonesia. Intisari Sains Medis 12(3): 757-762. D0I: 10.15562/ism.v12i3.1133

${ }^{1}$ Fakultas Kedokteran dan IImu Kesehatan, Universitas Warmadewa, Denpasar, Bali, Indonesia; ${ }^{2}$ Bagian IImu Kesehatan Anak Rumah Sakit Umum Daerah Wangaya, Denpasar, Bali, Indonesia;

\section{*Korespondensi:}

Made Cynthia Mahardika Putri;

Fakultas Kedokteran dan IImu Kesehatan, Universitas Warmadewa, Denpasar, Bali, Indonesia; cynthiamahardika@gmail.com

Diterima: 27-08-2021

Disetujui: 02-10-2021

Diterbitkan: 19-10-2021
Metode: Jenis penelitian yang digunakan adalah studi analitik observasional dengan pendekatan crosssectional. Pengambilan sampel menggunakan metode consecutive sampling. Data yang diperoleh dianalisis secara analitik, menggunakan program computer SPSS versi 25.0 dengan uji chi square dan uji independent t-test.

Hasil: Rerata RDW didapatkan lebih tinggi pada kelompok subjek dengan pneumonia berat $(15,48 \pm$ $1,95)$ dibandingkan kelompok dengan pneumonia ringan $(13,73 \pm 1,11)(p=0,000)$.

Simpulan: Terdapat hubungan bermakna antara RDW dengan tingkat keparahan pneumonia. mengetahui hubungan nilai RDW dengan tingkat keparahan pneumonia pada pasien anak.

Kata kunci: Red cell distribution width, pneumonia, keparahan.

Sitasi Artikel ini: Putri, M.C.M., Suryawan, I.W.B., Suarca, I.K. 2021. Hubungan nilai Red Cell Distribution Width (RDW) dengan tingkat keparahan pneumonia pada pasien anak di RSUD Wangaya Denpasar, Bali-Indonesia. Intisari Sains Medis 12(3): 757-762. D0l: 10.15562/ism.v12i3.1133 


\section{PENDAHULUAN}

Pneumonia pada anak sampai saat ini masih merupakan masalah kesehatan yang penting di dunia. Pneumonia merupakan penyebab kematian tertinggi pada anak usia kurang dari lima tahun. Setiap tahun terdapat sekitar 155 juta kasus pneumonia di seluruh dunia dengan jumlah kematian sekitar 1,8 juta anak balita, atau sekitar 20\% dari seluruh kematian balita di seluruh dunia. 99\% dari data kematian tersebut berasal dari negara-negara berkembang. Indonesia merupakan salah satu negara berkembang dengan angka morbiditas dan mortalitas pneumonia yang tinggi. ${ }^{1}$ Berdasarkan Profil Kesehatan Indonesia 2019 terdapat 466.524 atau 52,7\% kasus pneumonia anak di Indoneisa. Terdapat lebih dari 19.000 kematian balita atau dua anak meninggal setiap jam akibat pneumonia di tahun 2019. Prevalensi pneumonia pada populasi balita di Bali juga mengalami kenaikan dari 0,8\% pada 2013 menjadi $1 \%$ pada $2018 .^{2}$

Pneumonia merupakan penyakit infeksi yang mengakibatkan peradangan pada parenkim paru. Pneumonia sebagian besar disebabkan oleh mikroorganisme seperti bakteri, virus atau jamur dan sebagian kecil disebabkan oleh hal lain seperti aspirasi, radiasi dan lain-lain. ${ }^{3}$ Menurut WHO berdasarkan derajat penyakit, pneumonia diklasifikasikan menjadi pneumonia (tidak berat), pneumonia berat, dan pneumonia sangat berat. ${ }^{4}$

Pneumonia berat dan sangat berat kerap menimbulkan perburukan dan komplikasi hingga kematian. Komplikasi yang dapat terjadi berupa bakteremia (sepsis), abses paru, efusi pleura dan gagal napas. ${ }^{3}$ Adanya perburukan dan komplikasi yang timbul menyebabkan diperlukan perawatan di ruang intensif. Penelitian yang dilakukan Kaunang dkk di RSUP Prof Kandou Manado dari tahun 2013-2015 terdapat 158 kasus pneumonia pada anak yang memerlukan perawatan di ruang intensif. ${ }^{5}$ Penelitian oleh Hartawan dkk di RSUP Sanglah tahun 2018 menyebutkan bahwa dari 60 pasien anak terdapat 24 pasien anak dengan Comunity-Acquired Pneumonia (CAP) dan 3 pasien anak dengan HospitalAcquired Pneumonia (HAP) yang memerlukan perawatan PICU dengan bantuan ventilasi mekanik. ${ }^{6}$ Tingginya kasus pneumonia anak yang memerlukan perawatan PICU menandakan beratnya gejala yang timbul dan perburukan klinis yang terjadi, sehingga penting untuk menemukan penanda yang dapat memprediksi anak yang cenderung akan mengalami perburukan klinis sehingga dapat dilakukan pemantauan ketat dan terapi yang adekuat.

Red cell distribution width (RDW) adalah suatu penanda yang menggambarkan jumlah anisositosis (variasi ukuran sel) dan pada tingkat tertentu menggambarkan poikilositosis (variasi bentuk sel) sel darah merah. RDW dapat meningkat pada kondisi produksi sel darah merah yang tidak efektif, atau akibat peningkatan destruksi sel darah yang biasanya terjadi pada kondisi inflamasi atau infeksi. RDW merupakan komponen marker dari pemeriksaan darah lengkap standar namun nilai klinisnya jarang diperhatikan. ${ }^{7,8}$

Melihat tingginya kasus kematian pneumonia pada anak dan perburukan yang kerap terjadi hingga menyebabkan kematian maka penulis tertarik untuk melakukan penelitian mengenai hubungan antara RDW dengan tingkat keparahan pneumonia pada pasien anak.

\section{METODE}

Penelitian ini adalah suatu studi analitik observasional dengan pendekatan crosssectional. Data yang digunakan adalah data sekunder yang diperoleh dari rekam medis pasien. Penelitian ini dilakukan di Rumah Sakit Umum Daerah Wangaya, Kota Denpasar, Provinsi Bali yaitu di ruang rawat inap Kaswari dan PICU. Waktu dilakukan penelitian ini yaitu dari bulan Juli-Agustus 2021. Populasi target penelitian adalah semua pasien pneumonia anak yang berusia 1 bulan sampai dengan 17 tahun. Populasi terjangkau penelitian adalah pasien pneumonia anak yang berusia 1 bulan sampai dengan 17 tahun yang di RSUD Wangaya pada tahun 2019. Sampel penelitian adalah populasi terjangkau yang memenuhi kriteria inklusi dan eksklusi dan didapatkan dalam kurun waktu penelitian atau hingga memenuhi jumlah yang adekuat. Adapun kriteria inklusi pada penelitian ini adalah pasien pneumonia anak yang berusia 1 bulan sampai dengan 17 tahun yang di rawat di RSUD Wangaya pada tahun 2019. Sedangkan kriteria eksklusi adalah pasien dengan keadaan atau penyakit lain yang dapat mengganggu pengukuran maupun interpretasi yaitu anemia, penyakit hemolitik, perdarahan mayor, sepsis dan kanker.

Pada penelitian ini pemilihan sampel menggunakan teknik consecutive sampling dimana setiap pasien berusia 1 bulan-17 tahun yang dirawat dengan pneumonia di RSUD Wangaya pada tahun 2019 diikutsertakan sebagai subjek apabila memenuhi kriteria inklusi. Berdasarkan perhitungan yang dilakukan, diperoleh besarnya sampel minimal yang akan diteliti sebanyak 80 sampel. Seluruh subjek penelitian yang memenuhi kriteria inklusi dilakukan pencatatan dan penilaian awal seluruh variabel yang diteliti. Variabel meliputi jenis kelamin, usia, lama rawat, status gizi, tingkat keparahan pneumonia yang dibagi menjadi ringan dan berat berdasarkan skor pediatric respiratory severity score (PRESS), RDW, haemoglobin, white blood cell (WBC), dan trombosit. Setelah tercatat dara disajikan dalam bentuk deskriptif.

Analisis data dilakukan dengan analisis univariat untuk mendeskripsikan karakteristik responden dan analisis bivariat dilakukan dengan uji chi square untuk menguji hubungan antara jenis kelamin, usia, lama rawat dan status gizi dengan tingkat keparahan pneumonia. Sedangkan uji independent t-test digunakan untuk menguji hubungan antara nilai RDW, haemoglobin, WBC, dan trombosit dengan tingkat keparahan pneumonia. Data diolah menggunakan program komputer, yaitu Statistical Package for Social Science (SPSS) versi 25.0. Hasil dianggap bermakna bila $p$ value $<0.05$. Data disajikan dalam bentuk tabel distribusi frekuensi dan narasi. Penilaian dan keterangan kelaikan etik penelitian ini diberikan oleh Komisi Etika Penelitian Rumah Sakit Umum Daerah Wangaya Denpasar.

\section{HASIL}

Dari hasil penelitian ini, didapatkan 80 pasien anak dengan pneumonia yaitu 40 pasien anak dengan pneumonia ringan dan 40 pasien anak dengan pneumonia 
berat. Karakteristik sampel penelitian dapat dilihat pada Tabel 1.

Rerata RDW didapatkan lebih tinggi pada kelompok subjek dengan pneumonia berat $(15,48 \pm 1,95)$ dibandingkan kelompok dengan pneumonia ringan $(13,73 \pm 1,11)(\mathrm{p}=0,000)$. Pada kelompok subjek dengan pneumonia berat $(10,55 \pm$ $1,47)$ juga didapatkan rerata hemoglobin yang lebih rendah dibandingkan kelompok subjek dengan pneumonia ringan $(11,69 \pm 1,60) \quad(p=0,001)$. Tidak didapatkan perbedaan yang signifikan antara nilai WBC maupun trombosit pada kedua kelompok subjek (Tabel 2).

\section{PEMBAHASAN}

Subjek penelitian didominasi oleh kelompok usia 13-59 bulan (85\%). Hal ini sesuai dengan penelitian yang dilakukan oleh Dani dan Mairi pada tahun 2013 yang menyatakan proporsi pneumonia terbanyak pada usia 13-59 bulan (53,3\%). ${ }^{9}$ Penelitian Nurjannah tahun 2012 juga menunjukkan usia terbanyak mengalami pneumonia yaitu usia dua hingga sebelas bulan $68 \%$, selanjutnya usia satu tahun hingga lima tahun sebanyak $25,1 \%$ dan usia lebih dari 5 tahun sebanyak 25,1\%. ${ }^{10}$ Hal ini dikarenakan sistem imun tubuh belum berkembang sempurna pada

Tabel 1. Karakteristik sampel penelitian.

\begin{tabular}{llc}
\hline Karakteristik sampel penelitian & & Sampel \\
\hline Jenis Kelamin, $\mathrm{n}(\%)$ & Laki-laki & $44(55)$ \\
& Perempuan & $36(45)$ \\
Usia, $\mathrm{n}(\%)$ & $13-59$ bulan & $68(85)$ \\
& $\geq 60$ bulan & $12(15)$ \\
Lama rawat, $\mathrm{n}(\%)$ & $\leq 5$ hari & $57(71,2)$ \\
& $>5$ hari & $23(28,8)$ \\
Status Gizi, $\mathrm{n}(\%)$ & Obesitas & $6(7,5)$ \\
& Gizi Lebih & $8(10)$ \\
& Gizi Baik & $33(41,2)$ \\
Tingkat Keparahan, $\mathrm{n}(\%)$ & Gizi Kurang & $33(41,2)$ \\
& Ringan & $40(50)$ \\
RDW $(\%) ;$ rerata \pm SD & Berat & $40(50)$ \\
Hemoglobin $(\mathrm{g}) ;$ rerata $\pm \mathrm{SD}$ & & $14,60 \pm 1,80$ \\
WBC $\left(10^{3} / \mu \mathrm{l}\right) ;$ rerata $\pm \mathrm{SD}$ & & $11,12 \pm 1,63$ \\
Trombosit $\left(10^{3} / \mu \mathrm{l}\right) ;$ rerata $\pm \mathrm{SD}$ & & $14,33 \pm 1,14$ \\
\hline
\end{tabular}

beberapa tahun awal kehidupan. ${ }^{11}$

Pada penelitian ini juga didapatkan subjek laki-laki lebih dominan (55\%) dibandingkan subjek perempuan (45\%). Hasil penelitian ini sejalan dengan penelitian yang dilakukan oleh Kaunang dkk tahun 2016 dimana sampel penelitian didominasi oleh laki-laki sebanyak 53,3\%. ${ }^{5}$ Penelitian oleh Kristanto W dkk tahun 2018 juga menyebutkan anak laki-laki lebih dominan mengalami pneumonia yaitu sebanyak $16(53,3 \%)$ dari total 30 sampel. ${ }^{7}$ Hal ini dikarenakan respon sel imun T-helper 1 (Th1) diketahui lebih hebat pada anak perempuan. ${ }^{12}$

Status gizi pada penelitian ini didominasi oleh gizi baik dan gizi kurang yaitu sebanyak 33 subjek (41,2\%). Namun tidak berhubungan dengan tingkat keparahan pneumonia. Hal ini tidak sejalan dengan penelitian yang dilakukan oleh Artawan dkk tahun 2016 yang menyatakan status gizi berhubungan dengan tingkat keparahan pneumonia. Disebutkan bahwa malnutrisi memiliki risiko 2,176 kali lebih besar menyebabkan derajat pneumonia lebih berat. Pasien dengan malnutrisi mengalami masalah dalam imunitas khususnya IgA yang mengakibatkan penurunan sistem imun dan memperparah derajat infeksi. ${ }^{13}$ Penelitian yang dilakukan oleh Purnama MY dkk tahun 2021 menyebutkan bahwa terdapat hubungan antara status gizi dengan derajat keparahan pneumonia pada pasien balita, diamana balita dengan status gizi kurang dan buruk dapat meningkatkan derajat keparahan

Tabel 2. Hubungan karakteristik dasar dengan tingkat keparahan pneumonia.

\begin{tabular}{|c|c|c|c|c|}
\hline \multicolumn{2}{|c|}{$\begin{array}{l}\text { Hubungan karakteristik dasar dengan tingkat keparahan } \\
\text { pneumonia }\end{array}$} & \multirow{2}{*}{$\begin{array}{c}\begin{array}{c}\text { Ringan } \\
(\mathbf{n}=40)\end{array} \\
26(59,1)\end{array}$} & \multirow{2}{*}{$\begin{array}{c}\begin{array}{c}\text { Berat } \\
(\mathbf{n}=40)\end{array} \\
18(40,9)\end{array}$} & \multirow{2}{*}{$\frac{\mathbf{P}}{0,072}$} \\
\hline Jenis Kelamin, n (\%) & Laki-laki & & & \\
\hline & Perempuan & $14(38,9)$ & $22(61,1)$ & \\
\hline \multirow[t]{2}{*}{ Usia, n (\%) } & 13-59 bulan & $33(48,5)$ & $35(51,5)$ & 0,531 \\
\hline & $\geq 60$ bulan & $7(58,3)$ & $5(41,7)$ & \\
\hline \multirow[t]{2}{*}{ Lama rawat, $\mathrm{n}(\%)$} & $\leq 5$ hari & $32(56,1)$ & $25(43.9)$ & 0,084 \\
\hline & $>5$ hari & $8(34.8)$ & $15(65.2)$ & \\
\hline \multirow[t]{4}{*}{ Status Gizi, n (\%) } & Obesitas & $2(33,3)$ & $4(66,7)$ & 0,831 \\
\hline & Gizi Lebih & $4(50)$ & $4(50)$ & \\
\hline & Gizi Baik & $16(48,5)$ & $17(51,5)$ & \\
\hline & Gizi Kurang & $18(54,5)$ & $15(45,5)$ & \\
\hline $\mathrm{RDW}(\%)$; rerata $\pm \mathrm{SD}$ & & $13,73 \pm 1,11$ & $15,48 \pm 1,95$ & 0,000 \\
\hline Hemoglobin $(\mathrm{g})$; rerata \pm SD & & $11,69 \pm 1,60$ & $10,55 \pm 1,47$ & 0,001 \\
\hline $\mathrm{WBC}\left(10^{3} / \mu \mathrm{l}\right) ;$ rerata $\pm \mathrm{SD}$ & & $13,89 \pm 6,19$ & $14,76 \pm 15,13$ & 0,737 \\
\hline Trombosit $\left(10^{3} / \mu \mathrm{l}\right)$; rerata $\pm \mathrm{SD}$ & & $403,32 \pm 143,90$ & $420,98 \pm 173,47$ & 0,622 \\
\hline
\end{tabular}


pneumonia. ${ }^{14}$

Terdapat 57 anak $(71,2 \%)$ yang dirawat selama $\leq 5$ hari. Hasil penelitian ini sejalan dengan penelitian yang dilakukan oleh Kurniawati (2020) mendapatkan 39 balita $(56,5 \%)$ dengan pneumonia yang lama perawatan $\leq 5$ hari. Faktor yang menyebabkan lama perawatan tergantung pada status gizi, berat penyakit, serta penyakit penyerta. Lama perawatan dipengaruhi oleh derajat pneumonia. Semakin berat pneumonia maka semakin lama perawatan yang dilakukan pasien. ${ }^{15}$

Pneumonia merupakan penyebab kematian tertinggi pada anak usia kurang dari lima tahun khususnya di negara berkembang. ${ }^{1}$ Tingginya kasus kematian akibat pneumonia pada anak menandakan beratnya gejala yang timbul dan perburukan klinis yang terjadi, sehingga penting untuk menemukan penanda yang dapat memprediksi anak yang cenderung akan mengalami perburukan klinis sehingga dapat dilakukan pemantauan ketat dan terapi yang adekuat pada anak tersebut. Red cell distribution width (RDW) adalah suatu penanda yang menggambarkan jumlah anisositosis (variasi ukuran sel) dan pada tingkat tertentu menggambarkan poikilositosis (variasi bentuk sel) sel darah merah. RDW dapat meningkat pada kondisi produksi sel darah merah yang tidak efektif, atau akibat peningkatan destruksi sel darah yang biasanya terjadi pada kondisi inflamasi atau infeksi. ${ }^{7,8}$ RDW merupakan komponen marker dari pemeriksaan darah lengkap standar namun nilai klinisnya jarang diperhatikan. Belum banyak penelitian yang menghubungkan nilai RDW pada pasien pneumonia anak.

Terdapat beberapa skor yang digunakan untuk menentukan derajat keparahan pneumonia. Skor tersebut antara lain adalah PSI (Pneumonia Severity Index), CURB-65, CRB-65, RISC (Respiratory Index of Severity in Children), SMART-COP, PRESS, dan skor PIRO. ${ }^{16}$ Pada penelitian ini tingkat keparahan diukur dengan menggunakan skor PRESS. Skor ini digunakan karena sederhana dan dapat diaplikasikan di tempat penelitian. Berdasarkan skor PRESS tingkat keparahan diklasifikasikan menjadi 3, yaitu ringan, sedang, dan berat. Dikatakan ringan bila jumlah skor 0-1, sedang:
2-3 dan berat bila jumlah skor $4-5 .{ }^{17,18}$ Pada penelitian ini tingkat keparahan dibedakan menjadi 2 yaitu ringan dan berat. Diklasifikasikan dalan tingkat keparahan ringan apabila termasuk dalam kategori skor PRESS ringan dan sedang, sedangkan berat apabila masuk dalam kategori skor PRESS berat.

Penelitian ini menggunakan sampel sebanyak 80 pasien anak dengan pneumonia, yang meliputi 40 pasien anak dengan pneumonia ringan dan 40 pasien dengan pneumonia berat. Pada penelitian ini didapatkan nilai RDW lebih tinggi pada kelompok dengan pneumonia berat $(15,48 \pm 1,95)$ dibandingkan pada kelompok dengan pneumonia ringan $(13,73 \pm 1,11)$. Terdapat hubungan yang signifikan antara nilai RDW dengan beratnya pneumonia yang terjadi $(\mathrm{p}=0,000)$. Hal ini sesuai dengan penelitan yang dilakukan oleh Kristanto W dkk yang menyatakan bahwa semakin tinggi nilai RDW maka semakin parah pneumonia yang terjadi. Pengukuran tingkat keparahan pneumonia pada penelitian ini menggunakan skor RISC dan PRESS. Nilai RDW juga memiliki hubungan bermakna dengan diagnosis pneumonia dimana semakin tinggi nilai RDW maka semakin parah diagnosis pneumonia $(\mathrm{p}=0,004){ }^{7}$ Namun hasil penelitian ini tidak sejalan dengan penelitian Irwansayah yang menyatakan nilai RDW tidak memiliki hubungan bermakna dengan tingkat keparahan yang diukur berdasarkan skor PSI $(p=0,046)$ namun menunjukkan korelasi positif antara RDW hari I dengan IV terhadap tingkat keparahan pneumonia menggunakan skor CURB-65 $(\mathrm{p}=0,001) .{ }^{8}$

Penelitian yang dilakukan Miranda SJ tahun 2017 di Filipina pada anak berusia 1-18 tahun menyimpulkan bahwa peningkatan RDW secara signifikan berhubungan dengan tingkat keparahan, komplikasi dan kematian pada pasien anak dengan pneumonia. RDW dapat menjadi alat prognostik dan penanda yang valid serta hemat biaya untuk menentukan tingkat keparahan pneumonia. ${ }^{19}$ Penelitian yang dilakukan Farghly $S$ et al menyatakan bahwa nilai RDW berkolerasi positif dengan PSI dan CURB-65 ( $p<0.001$ ). Nilai RDW yang lebih tinggi memiliki kecenderungan skor indeks keparahan yang lebih tinggi, dan mortalitas pasien yang lebih tinggi juga. ${ }^{20}$

Pada penelitian ini didapatkan hasil nilai RDW pada pasien dengan pneumonia berat memiliki rerata 15,48 $\pm 1,95$. Hasil ini sesuai dengan penelitian yang dilakukan oleh Braun et al yang menyatakan bahwa peningkatan RDW $>14,5 \%$ secara independen terkait dengan beratnya pneumonia yang dinilai dari lama rawat inap $>10$ hari, masuk ICU dan kematian pada pasien CAP anak. ${ }^{21}$ Penelitian yang dilakukan Hashemi $\mathrm{SM}$ et al menyatakan RDW yang tinggi berhubungan dengan risiko kematian yang lebih tinggi pada pasien anak yang dirawat di PICU. ${ }^{22}$ Penelitian Moustafa AN juga menyatakan RDW menjadi biomarker yang paling akurat untuk menentukan mortalitas pada pasien anak prasekolah dengan CAP. Didapatkan titik potong $>17,4$ dengan sensitivitas 90,9\% dan spesifisitas $92,1 \% .{ }^{23}$ Penelitian menyebutkan bahwa peningkatan RDW diatas $14 \%$ secara signifikan berhubungan dengan sel darah merah yang rigid dan sulit hancur, yang dapat menghambat aliran darah dalam mikrosirkulasi dan berkontribusi terhadap disfungsi organ hingga menyebabkan kematian. ${ }^{24}$

Pada pasien dengan pneumonia akan terjadi proses inflamasi yang menyebabkan keluarnya mediator-mediator pro inflamasi. Salah satu mediator yang berperan adalah interleukin-6 (IL-6) yang berperan meningkatkan ekspresi hepcidin. Hepcidin merupakan hormon yang diproduksi di hepar dan peningkatannya menyebabkan kurangnya absorbsi zat besi di usus dan menahan pengambilan zat besi dari sel yang akhirnya berakibat pada gangguan pembentukan sel darah merah. Hal ini menyebabkan ukuran sel darah merah yang beredar menjadi sangat beragam dan pada akhirnya meningkatkan nilai RDW. ${ }^{25,26}$

Teori lain adalah mekanisme hipoksia jaringan yang menyebabkan lonjakan produksi eritopoietin (EPO) oleh ginjal. Hal ini menyebabkan peningkatan kecepatan produksi sel darah merah dan juga meningkatkan ukuran sel darah merah. Ukuran RBC meningkat 0,25-0,5\% setelah terjadinya lonjakan EPO sehingga akan menyebabkan makrosit dan monosit keluar secara bersamaan dan tercatat sebagai peningkatan RDW. Makrosit 
memiliki kemampuan mengangkut oksigen yang rendah dan memiliki rentang hidup hanya berkisar 1-2 bulan. ${ }^{6}$

Rerata kadar hemoglobin pada pasien pneumonia berat sebesar 10,55 $\pm 1,47$ lebih rendah dibandingkan pasien dengan pneumonia ringan yaitu 11,69 $\pm 1,60$. Terdapat hubungan yang bermakna antara kadar $\mathrm{Hb}$ dengan tingkat keparahan pneumonia $(p=0,001)$. Hal ini dapat dikaitkan dengan nilai RDW, dimana jika kadar $\mathrm{Hb}$ rendah maka jaringan akan mengalami hipoksia dan merangsang ginjal untuk mengeluarkan EPO dan menyebabkan variasi ukuran sel darah yang tercatat sebagai peningkatan RDW. Penelitian yang dilakukan oleh Hartawan dkk menyebutkan terdapat korelasi moderat anatara nilai $\mathrm{Hb}$ dengan $\mathrm{RDW}$ $(\mathrm{r}=0,43){ }^{6}$

Penelitian ini memiliki kekurangan, yaitu jumlah sampel yang tidak cukup besar yang dapat mempengaruhi hasil penelitian.

\section{SIMPULAN}

Terdapat hubungan bermakna antara RDW dengan tingkat keparahan pneumonia. Diharapkan dapat dilakukan penelitian lebih lanjut dengan jumlah sampel yang lebih besar sehingga diperoleh hasil yang dapat mewakili dan direpresentasikan dengan lebih baik pada populasi.

\section{KONFLIK KEPENTINGAN}

Penulis menyatakan tidak terdapat konflik kepentingan terkait publikasi dari artikel ini.

\section{PENDANAAN}

Penulis menyatakan tidak terdapat hibah dana terkait publikasi dari artikel ini baik dari pemerintah ataupun lembaga swasta lainnya.

\section{KONTRIBUSI PENULIS}

Seluruh penulis telah berkontribusi terhadap penyusunan dari naskah penelitian ini, dan setuju terhadap versi akhir untuk dilakukan publikasi.

\section{ETIKA DALAM PENELITIAN}

Penelitian ini telah mendapatkan persetujuan dari direktur RSUD Wangaya dan juga telah disetujui oleh Departemen Anak RSUD Wangaya Denpasar, Bali, Indonesia.

\section{DAFTAR PUSTAKA}

1. Mahalastri NND. The Correlation Between Indoor Air Pollution with the Incident of Toddler's Pneumonia. J Berk Epidemiol. 2014;2(3):392. Available from: http://dx.doi. org/10.20473/jbe.v2i32014.392-403

2. Oktaria V, Danchin M, Triasih R, Soenarto Y, Bines JE, Ponsonby AL, Clarke MW, Graham $\mathrm{SM}$. The incidence of acute respiratory infection in Indonesian infants and association with vitamin $\mathrm{D}$ deficiency. PLoS One. 2021;16(3):e0248722. doi: 10.1371/journal. pone. 0248722 .

3. Kliegman RM. Nelson Textbook of Pediatrics. Elsevier; 2011. p. 1404-1405.e1. Available from: http://dx.doi.org/10.1016/b978-1-4377-07557.00351-1

4. Graham SM, English M, Hazir T, Enarson $\mathrm{P}$, Duke T. Challenges to improving case management of childhood pneumonia at health facilities in resource-limited settings. Bull World Health Organ. 2008;86(5):349-55. Available from: https://pubmed.ncbi.nlm.nih. gov/18545737

5. Kaunang CT, Runtunuwu AL, Wahani AMI. Gambaran karakteristik pneumonia pada anak yang dirawat di ruang perawatan intensif anak RSUP Prof. Dr. R. D. Kandou Manado periode 2013 - 2015. e-CliniC. 2016;4(2). Available from: http://dx.doi.org/10.35790/ ecl.4.2.2016.14399

6. Ryalino C, Budi Hartawan In, Saputra Y. Correlation of red cell distribution width value with the duration of mechanical ventilator usage in patients treated in pediatric intensive care unit. Bali J Anesthesiol. 2020;4(3):99. Available from: http://dx.doi.org/10.4103/bjoa. bjoa_27_20

7. Kristianto W, Setyoningrum RA, Boediono A. Red-Cell Distribution Width (RDW) dan Mean Platelet Volume (MPV) sebagai Biomarker Keparahan Pneumonia Anak. Sari Pediatr. 2018;19(6):335. Available from: http://dx.doi. org/10.14238/sp19.6.2018.335-41

8. Andriyani S, Keliat EN, Abidin A. Hubungan Derajat Skor CURB-65 Saat Awal Masuk dan Nilai Antitrombin III pada Pasien Pneumonia Komunitas. Maj Kedokt Bandung. 2016;48(2):92-8. Available from: http://dx.doi. org $/ 10.15395 / \mathrm{mkb} . v 48 \mathrm{n} 2.762$

9. Oktaria V, Triasih R, Graham SM, Bines JE, Soenarto Y, Clarke MW, Lauda M, Danchin M. Vitamin D deficiency and severity of pneumonia in Indonesian children. PLoS One. 2021;16(7):e0254488. Available from: doi: 10.1371/journal.pone.0254488. PMID: 34242372; PMCID: PMC8270442.

10. Nurjannah N, Sovira N, Anwar S. Profil Pneumonia pada Anak di RSUD Dr. Zainoel Abidin, Studi Retrospektif. Sari Pediatr. 2016;13(5):324. Available from: http://dx.doi. org/10.14238/sp13.5.2012.324-8
11. Lim WS. Pneumonia-Overview. Reference Module in Biomedical Sciences. 2020:B9780-12-801238-3.11636-8. Available from: doi: 10.1016/B978-0-12-801238-3.11636-8.

12. Muenchhoff M, Goulder PJR. Sex differences in pediatric infectious diseases. J Infect Dis. 2014;209 Suppl 3(Suppl 3):S120-6. Available from: https://pubmed.ncbi.nlm.nih. gov/24966192

13. Artawan A, Purniti PS, Sidiartha IGL. Hubungan antara Status Nutrisi dengan Derajat Keparahan Pneumonia pada Pasien Anak di RSUP Sanglah. Sari Pediatr. 2016;17(6):418. Available from: http://dx.doi.org/10.14238/ sp17.6.2016.418-22

14. Rizqullah N-, Putri M, Zulmansyah Z. Hubungan Status Imunisasi Dasar terhadap Pneumonia pada Pasien Balita Rawat Inap di RSIA Respati Tasikmalaya. J Integr Kesehat Sains. 2021;3(1):19-23. Available from: http:// dx.doi.org/10.29313/jiks.v3i1.7296

15. Kurniawati S. Korelasi antara Status Gizi dengan Derajat Community Acquired Pneumonia (CAP) Pada Pasien Balita di RSUP Dr Sardjito Yogyakarta. Skripsi. FK Farmasi Universitas Sanata Dharma Yogyakarta; 2020.

16. Uwaezuoke SN, Ayuk AC. Prognostic scores and biomarkers for pediatric community-acquired pneumonia: how far have we come? Pediatr Heal Med Ther. 2017;8:9-18. Available from: https://pubmed.ncbi.nlm.nih.gov/29388605

17. Karakioulaki M, Stolz D. Biomarkers and clinical scoring systems in community-acquired pneumonia. Ann Thorac Med. 2019;14(3):165172. Available from: doi: 10.4103/atm. ATM_305_18.

18. Shim JY, Shim JW, Kim DS, Jung HL, Park MS. Atopic Sensitization Increases Severity Of H1N1 Virus-Associated Lower Respiratory Tract Infection In Children [Internet]. C25. Pediatric Respiratory Infections. American Thoracic Society; 2011. Available from: http://dx.doi. org/10.1164/ajrccm-conference.2011.183.1_ meetingabstracts.a4152

19. Miranda SJ. Validity of Red Cell Distribution Width as a Predictor of Clinical Outcomes in Pediatric Patients Diagnosed With Pneumonia. Chest. 2017;152(4):A843. Available from: http://dx.doi.org/10.1016/j.chest.2017.08.877

20. Farghly S, Abd-Elkader R, El Zohne RA, Abd El-Kareem DM. Mean platelet volume change $(\triangle \mathrm{MPV})$ and red blood cell distribution width (RDW) as promising markers of communityacquired pneumonia (CAP) outcome. Egypt J Bronchol. 2020;14(1). Available from: http:// dx.doi.org/10.1186/s43168-020-00024-z

21. Braun E, Kheir J, Mashiach T, Naffaa M, Azzam ZS. Is elevated red cell distribution width a prognostic predictor in adult patients with community acquired pneumonia? BMC Infect Dis. 2014;14:129. Available from: https:// pubmed.ncbi.nlm.nih.gov/24597687

22. Khanbabaee G, Hashemi SM, Salarian S, Fariborzi MR, Kiumarsi A. Red Cell Distribution Width Elevation and Sepsis in Pediatric Critically Ill Patients. Arch Pediatr Infect Dis. 2018;6(2). Available from: http:// dx.doi.org/10.5812/pedinfect.12210 
23. Mahmood N, Zaidi H, Patel V, Ali MI, Azam H, DeBari V, et al. Red Blood Cell Distribution Width As A Prognostic Indicator In Community-Acquired Pneumonia. A54. Assessing Severity Of Disease In Patients With Community Acquired Pneumonia. American Thoracic Society; 2012. Available from: $\quad$ http://dx.doi.org/10.1164/ajrccmconference.2012.185.1_meetingabstracts.a1804

24. Aostafa A, Haridi H, Ahmed M, Taghreed G.,Madani ME. Red Cell Distribution Width as a Marker of Inflammation in Type 2 Diabetes
Mellitus. Med J Cairo Univ. 2018;86(9):228795. Available from: http://dx.doi.org/10.21608/ mjcu.2018.57522

25. Handbook of Interventional Radiologic Procedures, 4th edKandarpaKrishna and MachanLindsay Philadelphia, Pa: Wolters Kluwer Lippincott Williams \& Wilkins, 2011. Available from: http://dx.doi.org/10.1148/ radiol.12124007

26. Allen LA, Felker GM, Mehra MR, Chiong JR, Dunlap SH, Ghali JK, et al. Validation and potential mechanisms of red cell distribution width as a prognostic marker in heart failure. J Card Fail. 2010;16(3):230-8. Available from: https://pubmed.ncbi.nlm.nih.gov/20206898

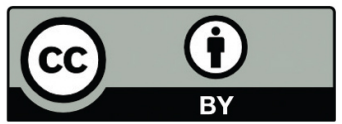

This work is licensed under a Creative Commons Attribution 